\title{
PENERAPAN MODEL PEMETAAN KONSEP DALAM PENINGKATAN PEMBELAJARAN BERMAKNA PADA MATA KULIAH LANDASAN PENDIDIKAN
}

\author{
1)Pupun Nuryani \\ ${ }^{1}$ Dosen pada Departemen Pedagogik Program Studi PGSD. FIP UPI.
}

\begin{abstract}
This research is motivated by the need for improvements to be made meaningful learning course on educational foundation, background PGSD students level 1 (one) following subjects educational foundation educational background in high school are usually / almost all have not understood the concept of education, causing some negative things in the implementation of learning, among others, the absence of transactional patterns of learning, and the lack of enthusiasm of students in the following subjects educational foundation. The study was conducted using a mixed method design methodology for quantitative, and qualitative approaches are integrated and support each other, which is the subject of research is PGSD students (1st semester). The results show that through application of models of concept mapping students get meaningful learning this can be seen during the lecture students more communicative, students' ability to master and understand the material more comprehensive and meanin gful learning course on Basis of Education can be seen from the test results of pre-test and post-test results test.Berdasarkan findings obtained in the study of the concept mapping model in the improvement of meaningfullearning in the subiect of Education Platform, some suggestions addressed to the following parties: For the majors
\end{abstract}

Keywords : Learning Through Concept Mapping Model

\section{A. PENDAHULUAN}

Mata kuliah Landasan
Pendidikan merupakan kelompok
mata kuliah dasar Kependidikan
yang memberi bekal sangat penting
kepada mahasiswa. Semua materi
mata kuliah landasan pendidikan
merupakan bekal bagi para
mahasiswa calon pendidik agar dapat
melaksanakan praktek pendidikan dengan tepat dan benar.

M.J. Dunkin dan B.J. Bidle dalam bukunya The Study of Teaching (1974) yang dikutip Redja Mudyahardjo (1998) menyaatakan ada empat variable yang terlibat dalam pembelajaran, yaitu (1) variable karakteristik kepribadian guru (presage variables), (2) variable karakteristik siswa (context variables), (3) variable proses interaksi guru-siswa di kelas (process variables), dan (4) variable hasil (product variables). Untuk lebih jelasnya hubungan keempat variable tersebut dapat dilihat pada gambar 1 berikut ini :

Latar belakang mahasiswa PGSD tingkat 1 (satu) yang mengikuti mata kuliah landasan pendidikan berlatar belakang pendidikan SLTA yang pada umumnya /hampir semua belum memahami konsep pendidikan sehingga menimbulkan beberapa hal negative dalam pelaksanaan pembelajaran, antara lain tidak terjadinya pola transaksional dalam pembelajaran, dan kurangnya antusias mahasiswa dalam mengikuti mata kuliah landasan pendidikan. 
Upaya yang dilakukan untuk mengatasi hal tersebut, dalam mata kuliah landasan pendidikan disediakan buku teks sebagai salah satu sumber belajar. Kenyataannya meskipun buku sumber dimiliki mahasiswa, hasilnya masih rendah mengingat cara menyimak bacaan buku teks yang dilakukan mahasiswa masih kurang efektif dan efisien. Oleh karena itu, dalam pembelajaran landasan pendidikan perlu melakukan inovatif melalui kegiatan penelitian ini akan menerapkan model pemetaan konsep dalam pembelajaran landasan pendidikan.

Pada mata kuliah landasan pendidikan yang ingin ditingkatkan adalah pemahaman mahasiswa terhadap materi perkuliahan yang diharapkan selanjutnya dapat diterapkan dalam kehidupannya terutama dalam profesinya sebagai pendidik.

Berdasarkan latar belakang masalah tersebut di atas, maka dalam penelitian ini berfokus pada permasalahan “ bagaimana penerapan model pemetaan konsep dalam peningkatan pembelajaran bermakna pada mata kuliah landasan pendidikan? ". Untuk membahas permasalahan tersebut peneliti ajukan beberapa pertanyaan penelitian, yaitu :

1. Bagaimana bentuk instrument standar pengukuran keberhasilan belajar mata kuliah landasan pendidikan ?

2. Bagaimana silabus mata kuliah landasan pendidikan baku berorientasi pada model pemetaan konsep ?

3. Bagaimana bentuk satuan acara perkuliahan (SAP) mata kuliah landasan pendidikan yang berorientasi pada model pemetaan konsep ?

4. Bagaimana penerapan model pemetaan konsep dalam mata kuliah landasan pendidikan ?

5. Bagaimana hasil uji mata kuliah landasan pendidikan dengan menerapkan model pemetaan konsep?

Secara umum tujuan dari penelitian ini adalah untuk meningkatkan mutu dan efisiensi proses pembelajaran pada mata kuliah landasan pendidikan di PGSD. Dan Secara khusus penelitian ini bentujuan untuk memperoleh data tentang :

1. Bentuk instrument standar pengukuran keberhasilan belajar mata kuliah landasan pendidikan

2. Silabus mata kuliah landasan pendidikan baku berorientasi pada model pemetaan konsep

3. Bentuk satuan acara perkuliahan (SAP) mata kuliah landasan pendidikan yang berorientasi pada model pemetaan konsep

4. Penerapan model pemetaan konsep dalam mata kuliah landasan pendidikan

5. Hasil uji mata kuliah landasan pendidikan dengan menerapkan model pemetaan konsep

Landasan konsepsi digunakan sebagai dasar berpijak dalam mengembangkan pemikiran lebih lanjut. Selain itu, landasan teori juga digunakan sebagai alat untuk mengamati suatu fenomena. Selanjutnya,landasan teori dapat digunakan pula sebagai alat dalam melakukan analisis penelitian. Adapun teori yang melandasi dalam penelitian ini adalah: 
B. KAJIAN LITERATUR

DevinisiMata Kuliah Landasan Pendidikan.

Landasan Pendidikan adalah mata kuliah yang diajarkan pada semua jurusan pendidikan di UPI Bandung dan merupakan satu mata kuliah yang termasuk rumpun Mata Kuliah Dasar Pendidikan (MKDP) sebanyak 2 SKS yang wajib diikuti semua mahasiswa calon guru atau pendidik.

Adapun tujuan setelah mengikuti perkuliahan ini secara tertib dan sungguh-sungguh mahasiswa diharapkan memiliki berbagai wawasan tentang asumsi pendidikan baik yang bersifat filosofis , ilmiah, seni, dan yuridis serta mampu mengaflikasikannya dalam praktek pendidikan lebih lanjut.

\section{Matakuliah}

ini mendeskripsikan materi tentang pengertian, fungsi dan jenis landasan pendidikan, konsep manusia sebagai asumsi pendidikan , konsep pendidikan, landasan filosofis pendidikan, landasan psikologi pendidikan, landasan sosiologis pendidikan, landasan antropologis pendidikan, landasan historis pendidikan dan landasan yuridis pendidikan. Perkuliahan dilaksanakan dengan pendekatan ekspository dan inquiry dalam bentuk ceramah, Tanya jawab , diskusi dan pemecahan masalah. Tahap penguasaan mahasiswa dievaluasi melalui UTS, UAS , tugas laporan bab dengan membuat peta konsep, presentasi dan partisipasi dalam diskusi. Buku sumber utama : Tim Dosen Mata Kuliah Landasan Pendidikan .
Materi Perkuliahan selama satu semester yaitu

a. Pengertian, fungsi, dan jenis landasan pendidikan

b. Manusia sebagai asumsi pendidikan

c. Pengertian pendidikan

d. Pendidikan sebagai ilmu dan seni

e. Landasasan filsafat pendidikan

f. Landasan Psikologi Pendidikan

g. Landasan sosiologin dan antropologia pendidikan

h. Landasan Historis Pendidikan

i. Landasan yuridis Pendidikan

\section{Model Pemetaan Konsep}

Model pemetaan konsep didasari oleh filsafat konstruktivisme yang menekankan bahwa pengetahuan dibentuk oleh siswa yang sedang belajar, dan teori perubahan konsep menjelaskan bahwa siswa mengalami perubahan konsep terus menerus. Konstruktivisme membantu untuk mengerti bagaimana siswa membentuk pengetahuan yang tidak tepat.Dengan demikian , seorang pendidik membantu mengarahkan siswa dalam pembentukan pengetahuan mereka yang lebih tepat. Teori perubahan konsep memberikan pemgertian bahwa setiap orang dapat membentuk pengertian yang berbeda . Hal tersebut diatas sesuai dengan tujuan dari konstrukstivisme, diantaranya : 1) Adanya motivasi untuk siswa bahwa belajar adalah tanggung jawab siswa sendiri. 2) Mengembangkan kemampuan siswa untuk mengajukan pertanyaan dan mencari sendiri pertanyaannya, 3) 
Membantu siswa untuk mengembangkan pengertian atau pemahaman kon sep secara lengkap. 4) Lebih menekankan pada proses belajar bagaimana belalar itu.

Berdasarkan tujuan tersebut diatas bahwa dalam pembelajaran dengan menggunakan perubahan konsep siswa dituntut untuk aktif serta membangun pengetahuannya sendiri berdasarkan kemampuan dan pengalaman pengalamannya sendiri sehingga akan terjadi perubahan konsep ilmiah dan guru disini berperan sebagai fasilitator dan mediator serta dapat menciptakan situasi sehingga proses konstruktivisme berjalan lancar. Hal ini sesuai dengan prinsip kontruktivisme , yaitu : a) Pengetahuan dibangun sendiri baik secara personal maupun social. b) Pengetahuan tidak dapat dipindahkan dari guru ke murid, kecuali hanya dengan keaktifan murid sendiri dengan belajar. c) Guru hanya sekedar membantu menyediakan sarana dan situasi agar proses konstruktivisme berjalan lancar. d) Murid aktif mengkontruksi terus menerus, sehingga selalu terjadi perubahan konsep ilmiah. e) Menghadapi masalah yang relevan dengan siswa. f) Struktur pembelajaran seputar konsep utama pentingnya sebuah pertanyaan. g) Mencari dan menilai pendapat siswa. h) Menyesuaikan kurikulum untuk menanggapi anggapan siswa. i) Menilai belajar siswa dalam konteks pengajaran. j) Implikasi konstruktivisme pada pembelajaran : 1) Setiap guru pernah mengalami menjelaskan materi atau membahas materi sejelas-jelasnya , namun masih ada siswa yang belum mengerti materi tersebut. Hal ini menunjukan bahwa guru dapat mengajar dengan baik, namun sebagian siswa tidak belajar sama sekali. Usaha guru dalam mengajar tidak harus selalu diikuti dengan hasil yang baik pada siswanya. Tetapi usaha keras sendiri siswalah yang akan betul-betul memahami materi tersebut. 2) Tugas setiap guru memfasilitasi siswanya sehingga pengetahuan tentang materi yang dibangun atau dikonstruksi oleh siswa sendiri bukan yang ditanam guru. 3) Untuk mengajar dengan baik, guru harus memahami modelmodel mental yang digunakan para siswa untuk mengenal dunia mereka dan penalaran yang dikembangkan yang dibuat para siswa untuk mendukung model-model itu. 4) Siswa perlu mengkonstruksi pemahamannya sendiri tentang materi sehingga guru bukan menguliahi, menerangkan atau memindahkan pengetahuan tetapi membantu perkembangan siswa membuat konstruksi-konstruksi mental yang diperlukan. 5) Latihan memecahkan masalah melalui belajar kelompok dengan menganalisis masalah dalam kehidupan seharihari. 6) Peserta didik diharapkan selalu aktif dan dapat menemukan cara belajar yang sesuai dengan dirinya. Guru sebagai fasilitator , mediator serta teman yang membuat situasi kondusif untuk terjadinya konstruksi pengetahuan pada diri siswa.

\section{Pengertian Pemetaan Konsep.}

Konsep dapat didefinisikan dengan berbagai macam rumusan. Carrol dalam kardi (1997 ; 2) konsep merupakan suatu abstraksi dari 
serangkaian pengalaman yang didefinisikan sebagai suatu obyek atau kejadian. Abstraksi adalah suatu proses pemusatan perhatian seseorang pada situasi tertentu dan mengambil elemen-elemen tertentu serta mengabaikan elemen yang lain. Oleh karena itu konsep-konsep merupakan penyajian internal dari sekelompok stimulus, konsepkonsep itu tidak diamati dan harus disimpulkan dari prilaku. Ausubel menyatakan bahwa konsep merpakan dasar untuk berfikir , untuk belajar aturan-aturan dan akhirnya untuk memecahkan masalah. Dengan demikian konsep itu sangat penting bagi manusia dalam berfikir dan belajar. George Posner dan Alan Rudnitsky dalam Nur ( 2001b;36 ) peta konsep mirip dengan peta jalan, namun peta konsep menaruh perhatian antar ideide, bukan hubungan antar tempat. Peta konsep menggambarkan konsep-konsep yang penting dan juga menghubungkan konsep-konsep yang penting.

Menurut Hudoyo peta konsep adalah saling keterkaitan antara konsep dan prinsip yg direfresentasikan bagai jaringan konsep yg dikonstruk dan jaringan konsep hasil konstruksi inilah yg disebut peta konsep, selanjutnya menurut Suparno ( Basuki 2000 , hal 9 ) peta konsep merupakan bagan skematik untuk menggambarkan suatu pengertian konseptual seseorang dlm suatu rangkaian pernyataan . Berdasarkan pengertian diatas dapat disimpulkan bahwa peta konsep adalah suatu gambaran yang memberikan arah yang mendasar dari suatu materi pelajaran sehingga dapat diketahui hubungan antar elemen dari suatu materi yang akan dipelajari atau dengan kata lain adanya jaringan yang saling berhubungan yang memberi kejelasan dan makna dari suatu materi yang akan dibahas.

Untuk membuat suatu peta konsep , siswa dilatih untuk mengidentifikasi ide-ide kunci yang berhubungan dengan suatu topik dan menyusun ide-ide tersebut dalam suatu pola logis. Maka menurut Dahar peta konsep memegang peranan penting dalam belajar bermakna. Oleh karena itu siswa hendaknya pandai menyusun peta konsep untuk meyakinkan bahwan siswa telah belajar bermakna.

\section{Ciri-ciri Model Pemetaan} Konsep

Ciri-ciri peta konsep menurut Ausubel ( Dahar 1988 )

a. Peta konsep atau pemetaan konsep adalah suatu cara untuk memperlihatkan konsep-konsep dan proposisipropisisi bidang studi apakah itu bidang studi fisika matematika kimia dll. Dengan membuat sendiri peta konsep siswa melihat bidang studi itu lebih jelas dan mempelajari bidang studi itu lebih bermakna

b. Suatu peta konsep merupakan suatu gambar dua dimensi dari suatu bidang studi atau suatu bagian bidang studi. Cirri inilah yang memperlihatkan hubungan proposional antar konsepkonsep . Hal inilah yang membedakan belajar bermakna dari belajar dengan mencatat pelajaran tanpa 
memperlihatkan hubungan antara konsep- konsep.

c. Menyatakan hubungan antar konsep-konsep, tidak semua konsep memiliki bobot yang sama, ini menandakan bahwa adan konsep-konsep yang inklusif dari pada konsepkonsep lain

d. Hirarkhi apabila dua atau lebih konsep digambarkan dibawah suatu konsep yang lebih inklusif, terbentuklah suatu hirarhi konsep tersebut.

\section{Langkah-langkah Model Pemetaan Konsep}

Menurut Ernes ada 5 langkah dalam penyusunan peta konsep yaitu :
a. Tentukan topiknya
b. Membuat daftar konsep
c. Menyusun konep-konsep menjadi sebuah bagan
d. Menghubungkan konsep- konsep itu dengan kata-kata supaya terbentuk proposisi
e. Mengevaluasi keterkaitan konsep-konsep yang telah dibuat

Sedangkan menurut Ausubel bahwa membuat peta konsep perlu ditempuh 4 langkah yaitu;

1) Mengidentifikasi ide pokok atau prinsip yang meliputi sejumlah konsep

2) Mengidentifikasi ide-ide atau konsep -konsep sekunder yang menunjang ide utama

3) Menempatkan ide utama ditengah atau di puncak peta tersebut.

4) Mengelompokan ide sekunder disekrlling ide utama yang secata visual menunjukkannhubungan ideide tersebut dengan ide utama

\section{Konsep Pembelajaran Bermakna}

Belajar pada hakekatnya merupakan proses perubahan di dalam kepribadian yang berupa kecakapan, sikap, kebiasaan dan kepandaian. Perubahan ini bersifat menetap dalam tingkah laku yang terjadi sebagai suatu hasil dari latihan atau pengalaman.

Pembelajaran pada hakekatnya adalah suatu proses interaksi antar anak dengan anak anak dengan sumber belajar, anak dengan pendidik. Kegiatan pembelajaran ini akan menjadi bermakna bagi anak jikan dilakukan dalam lingkungan yang nyaman dan memberikan rasa aman bagi anak.

Pembelajaran bermakna meaningfull learning ) merupakan suatu proses dikaitkannya informasi baru pada konsep-konsep relevan yang terdapat dalam struktur kognitif seseorang. Pembelajaran bermakna sebagai hasil dari peristiwa.

Mengajar ditandai oleh oleh terjadinya hubungan antara aspekaspek, konsep-konsep, , informasi atau situasi baru dengan komponenkomponen yang relevan di dalam struktur kognitip siswa. Proses belajar tidak hanya menghapal konsep-konsep atau fakta-fakta belaka, tetapi merupakan kegiatan menghubungkan konsep-konsep untuk menghasilkan pemahaman yang utuh, sehingga konsep yang dipelajari akan dipahami baik dan tidak mudah dilupakan.

Dengan demikian agar terjadi belajar bermakna guru harus menggali konsep-konsep yang 
dimiliki siswa dan dipadukan dengan pengetahuan baru.

Menurut Ausubel, Novak dan Hanesian ada dua jenis belajar : a) Belajar bermakna (meaningful learning). b) Belajar menghafal (rote learning).

Belajar bermakna adalah
suatu proses belajar dimana informasi baru dihubungkan dengan struktur pengertian yang sudah dipunyai sesorang yang sedang belajar. Belajar bermakna terjadi bila pelajar mencoba menghubungkan fenomena baru dengan konsep yang telah ada sebelumnya. Artinya bahwa belajar itu bermakna apabila pelajar menghubungkan pengetahuan baru atau informasi baru dengan kemampuan atau pengetahuan yang dimiliki siswa atau pelajar sehingga konsep-konsep baru tersebut benarbenar terserap olehnya dan bahan yang dipelajari haruslah bermakna.

Belajar menghapal bila konsep yang cocok dengan fenomena baru itu belum ada maka informasi baru tersebut harus dipelajari secara menghapal. Belajar menghafal itu perlu bila sesorang memperoleh informasi baru dalam dunia pengetahuan yang sama sekali tidak berhubungan dengan apa yang ia ketahui sebelumnya. Artinya bahwa belajar menghapal itu diperlukan apabila informasi itu tidak berhubungan dengan pengetahuan yang ia miliki sebelumnya.

Ausubel berpendapat bahwa belajar dapat diklasifikasikan kedalam dua dimensi ;

a. Berhubungan dengan cara informasi atau materi pelajaran itu disajikan melalui penerimaan atau penemuan. Disini siswa mencoba menghafalkan

informasi baru itu tanpa

menghubungkan dengan

struktur kognitifnya , maka

terjadilah belajar dengan

hafalan

b. .Berhubungan dengan bagaimana siswa dapat mengaitkan informasi itu pada struktur kognitif yang telah ada.Maka inilah yang disebut dengan belajar bermakna

Nasutioan

1982:158 menyimpulkan kondisi-kondisi belajar bermakna sebagai berikut :

a. Menjelaskan hubungan atau relevan bahan-bahan baru dengan bahan-bahan lama

b. Lebih dahulu diberikan ide yang paling umum dan kemudian hal-hal yang lebih terperinci

c. Menunjukan persamaan dan perbedaan antara bahan baru dengan bahan lama

d. Mengusahakan agar ide yang telah ada dikuasai sepenuhnya sebelum ide baru disajikan

Selanjutnya suatu pembelajaran dikatakann bermakna jika memenuhi persyaratan yaitu :

a. Materi yang akan dipelajari bermakna secara potensial. Artinya jika materi itu mempunyai kebermaknaan secara logis dan gagasan yang relevan harus terdapat pada struktur kognitif siswa.

b. Anak yang akan belajar harus bertujuan melaksanakan belajar bermakna sehingga anak tersebut mempunyai 
kesiapan dan niat dalam belajar bermakna

\section{Langkah-langkah belajar bermakna Menurut Ausubel adalah:}

a. Pengatur awal ( advance organizer )

Pengatur awal dapat digunakan untuk membantu mengaitkan konsep yang lama dengan konsep yang lebih tinggi maknanya

b. Diferensiasi Progresif

Dalam pembelajaran
bermakna perlu ada
pengembangan
kolaborasi konsep-konsep . Caranya unsure yang inklusif diperkenalkan terlebih dahulu kemudian baru lebih mendetil.

Faktor-faktor utama yang mempengaruhi belajar bermakna menurut Ausubel adalah struktur kognitif yang ada, stabilitas, dan kejelasan pengetahuan dalam suatu bidang studi tertentu dan pada waktu tertentu.

Sifat-sifat struktur kognitif menentukan validitas dan kejelasan arti-arti yang timbul waktu informasi baru masuk ke dalam struktur kognitif itu; demikian pula sifat proses interaksi yang terjadi. Jika struktur kognitif itu stabil, dan diatur dengan baik, maka arti-arti yang sahih dan jelas atau tidak meragukan akan timbul dan cenderung bertahan.

Sebaliknya jika struktur kognitif itu tidak stabil, meragukan, dan tidak teratur, maka struktur kognitif itu cenderung menghambat belajar dan retensi.
Ada tiga kebaikan dari belajar bermakna menurut Ausubel ( Dahar, 1989 : 141 ) yaitu:

a. Informasi yang dipelajari secara bermakna lebih lama dapat diingat

b. Informasi yang dipelajari secara bermakna memudahkan proses belajar berikutnya untuk materi pelajaran yang mirip

c. Informasi yang dipelajari secara bermakna mempermudah belajar hal-hal yang mirip walaupun telah terjadi lupa.

Berdasarkan hal tersebut diatas karena belajar bermakna itu mengkaitkan atau menghubungkan struktur kognitip yang dimiliki siswa dengan pengetahuan atau konsep baru sehingga akan lama untuk diingat berbeda dengan belajar menghafal. Pengetahuan yang diberikan selalu berkaitan dengan pengetahuan yang dimiliki siswa maka akan memudahkan dalam proses belajar dan akan mempermudah belajar apabila terjadi lupa karena materi selalu berkaitan. Jika struktur kognitif itu stabil tidak meragukan dan teratur akan mempermudah dalam belajar.

\section{METODE PENELITIAN}

Metode penelitian yang digunakan dalam kajian ini adalah analisis dokumentasi dan survey explanasi mengenai sejumlah tahapan dalam pengembangan sistem pembelajaran yang berlaku di lingkungan PGSD. 


\section{HASIL DAN PEMB AHASAN}

Berikut diuraikan hasil-hasil penelitian sesuai dengan rumusan masalah sekaligus capaian tujuan penelitian :

\section{a. Bentuk Instrument Standar Pengukuran Keberhasilan Belajar Mata Kuliah Landasan Pendidikan}

$\begin{array}{cc}\text { Untuk } & \begin{array}{c}\text { mengetahui } \\ \text { keberhasilan belajar mahiswa }\end{array}\end{array}$ PGSD khususnya yang menjadi sampel penelitian ini digunakan alat ukur yaitu berupa tes dan non-tes. Alat ukur keberhasilan belajar berupa tes berbentuk pilihan jamak (multiplechoice) dengan empat alternatif jawaban yaitu pilihan A, B, C dan D. Soal-soal pada alat tes (instrumen) yang berjumlah 50 butir tersebut dikembangkan berdasarkan silabus dan indikator pada mata kuliah Landasan Pendidikan yang menggunakan penerapan model pemetaan konsep. Instrumen yang digunakan berupa soal ujian, pada proses penelitian ini soal tidak melewati prosedur pengembangan alat ukur baku, baik uji validitas maupun reliabilitas secara empirik melainkan hanya melalui kajian tim peneliti dalam menyusun silabus, kompetensi dasar, indikator sampai penyusunan soal-soal yang di ujikan pada ujian tengah semester pada mata kuliah Landasan Pendidikan.

Instrumen yang di gunakan untuk menilai keberhasilan belajar pada mata kuliah Landasan Pendidikan selain menggunakan tes juga menggunakan pedoman observasi. Instrumen observasi digunakan untuk menilai keberhasilan proses pembelajaran yang dilakukan mahasiswa dengan menerapkan model pemetaan konsep.

Secara keseluruhan instrumen dalam penelitian ini digunakan sebagai alat uji keberhasilan dari penerapan model pemetaan konsep baik pada kegiatan pre-test maupun pada kegiatan post-test. Instrumen ini dapat juga digunakan oleh dosen untuk mengukur keberhasilan belajar mahasiswa khususnya mahasiswa PGSD yang mempelajari mata kuliah Landasan Pendidikan.

\section{b. Silabus Mata Kuliah Landasan Pendidikan Baku Berorientasi pada Model Pemetaan Konsep}

Silabus mata kuliah yang dikembangkan terdiri dari tujuan pembelajaran khusus (performansi.indikator), sub pokok bahasan dan rincian materi, proses pembelajaran (kegiatan mahasiswa), tugas dan evaluasi, media dan sumber buku.

Pada bagian tujuan pembelajaran khusus yang dikembangkan mencakup a) standar kompetensi, b) kompetensi dasar, c) materi pokok pembelajaran, d) indikator, f) alokasi waktu dan g) sumber belajar.

Kegiatan pembelajaran fokus pada presentasi dan diskusi dengan menerapkan model pembelajaran pemetaan konsep. Evaluasi penilaian menggunakan pedoman observasi dan dilakukan Quiz yang disesuaikan dengan materi yang telah dipelajari sedangkan secara sumatif digunakan sebagai soal ujian tengah semester. Bahan ajar berupa panduan handout. 


\section{c. Bentuk satuan acara} perkuliahan (SAP) Mata Kuliah Landasan Pendidikan yang Berorientasi pada Model Pemetaan Konsep

(SAP) $\begin{array}{lr}\text { Satuan Acara Perkuliahan } \\ \text { dikembangkan dengan }\end{array}$ memuat bagian identitas yang mencakup: a) mata kuliah, b) jurusan/semester, c) pertemuan ke-, d) alokasi waktu, e) standar kompetensi, f) kompetensi dasar, g) indikator, ditambah dengan enam komponen SAP yaitu: 1) tujuan perkuliahan, 2) materi ajar, 3) metode pembelajaran, 4) langkahlangkah pembelajaran, 5) alat/bahan/sumber belajar dan 5) penilaian.

\section{d. Penerapan Model Pemetaan Konsep dalam Mata Kuliah Landasan Pendidikan}

Untuk menerapkan model pemetaan konsep pada mata kuliah Landasan Pendidikan, mahasiswa dilatih untuk mengidentifikasi ideide kunci yang berhubungan dengan suatu topik dan menyusun ide-ide tersebut dalam suatu pola logis. Maka penerapan peta konsep memegang peranan penting dalam belajar bermakna. Oleh karena itu mahasiswa hendaknya pandai menyusun peta konsep untuk meyakinkan bahwan mereka mampu mencapai pembelajaran yang bermakna.

Penerapan model pemetaan konsep pada mata kuliah Landasan Pendidikan dalam penelitian ini membahas sampai dengan setengah semester yaitu dimulai dari pembahasan mengenai manusia dan pendidikan, pengertian pendidikan, pendidikan sebagai ilmu dan seni dan pembahasan mengenai landasan filosofis pendidikan

Pembahasan setiap materi dibuat dengan menggunakan pemetaan konsep, hal ini di jabarkan sebagai berikut:

1) Manusia dan Pendidikan

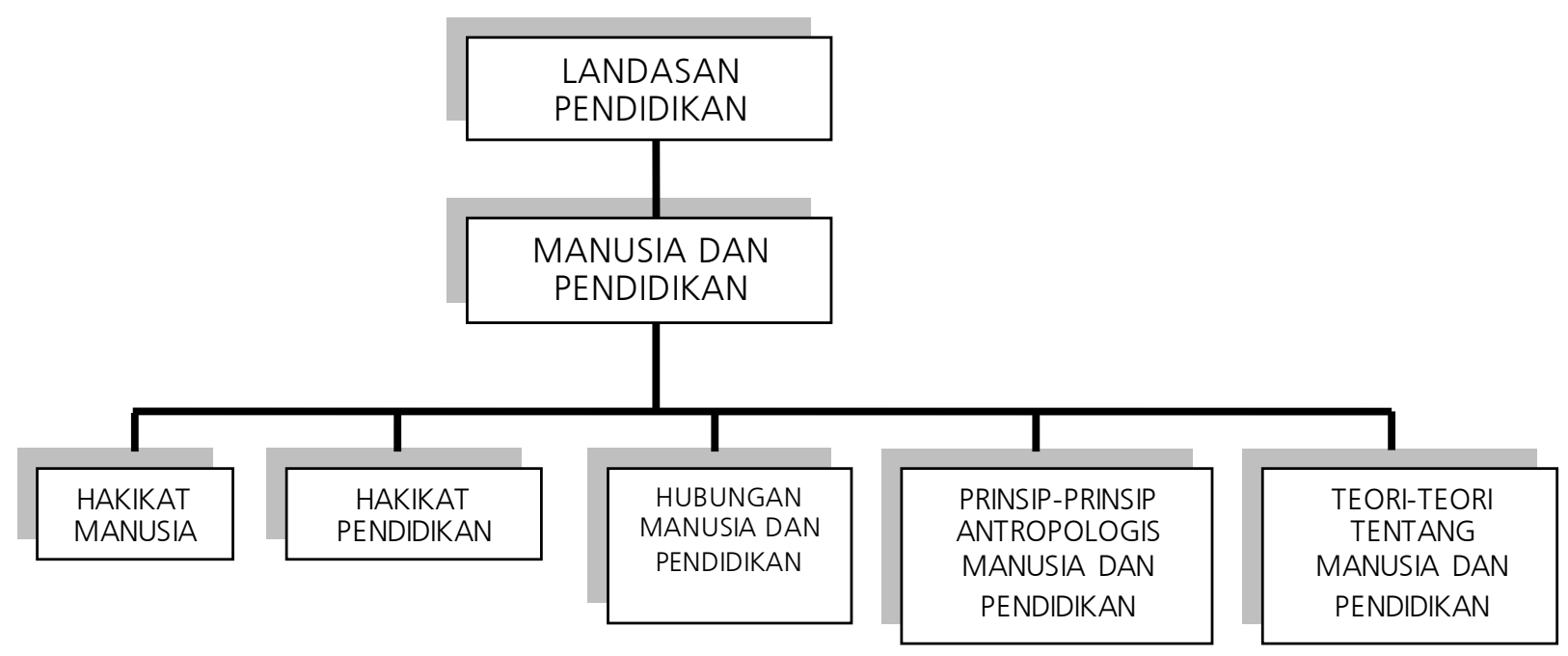




\section{Bagan.1}

Peta konsep materi Manusia dan Pendidikan

\section{2) Pengertian Pendidikan}

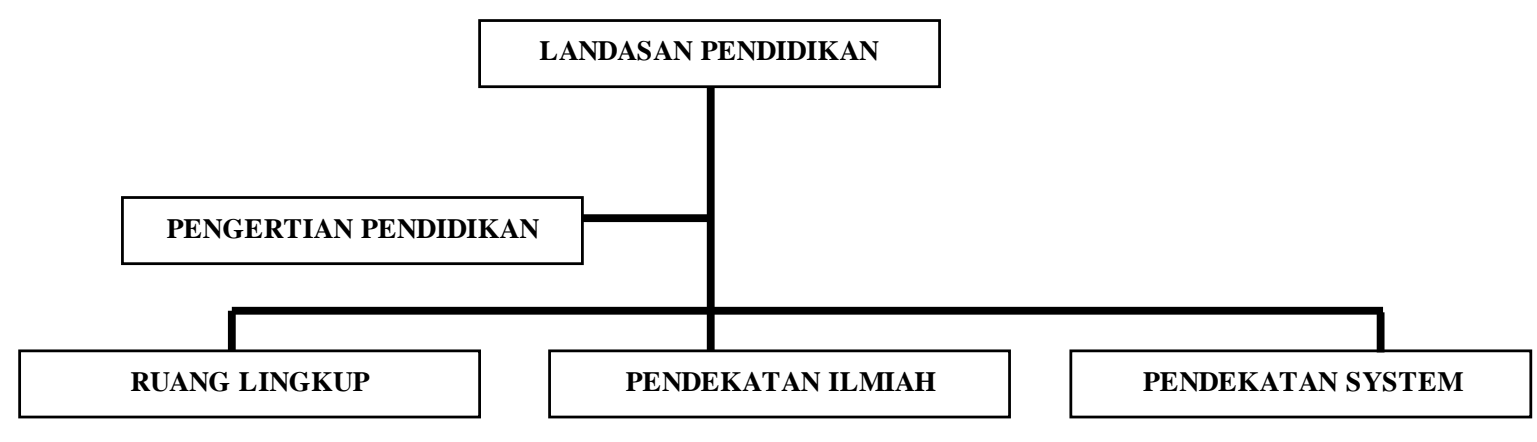

Bagan 2

Peta konsep materi Pengertian Pendidikan

3) Pendidikan Sebagai Ilmu dan Seni

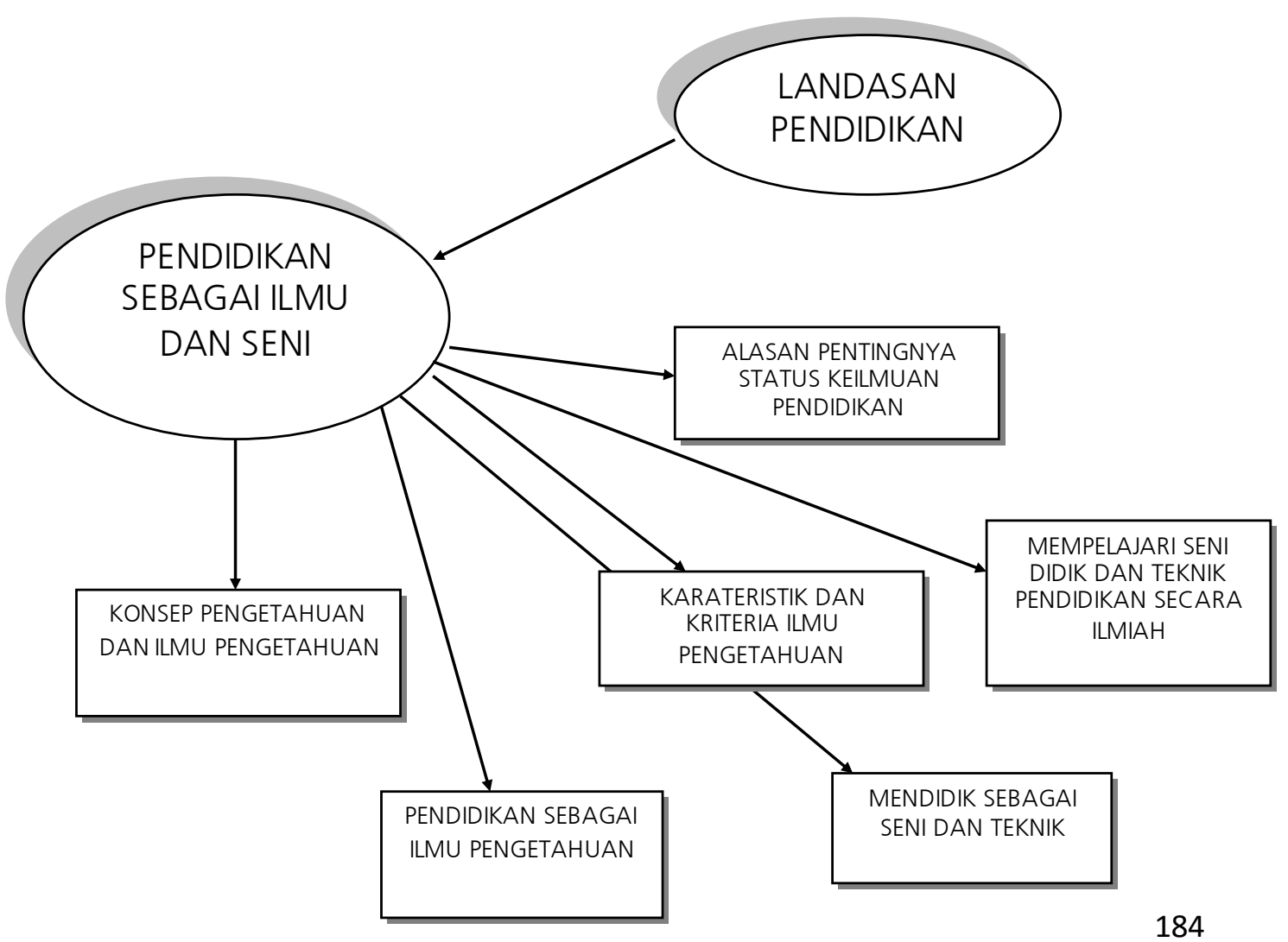




\section{Bagan.3 \\ Peta konsep materi Pendidikan sebagai Ilmu dan Seni}

\section{4) Landasan Filos ofis Pendidikan}

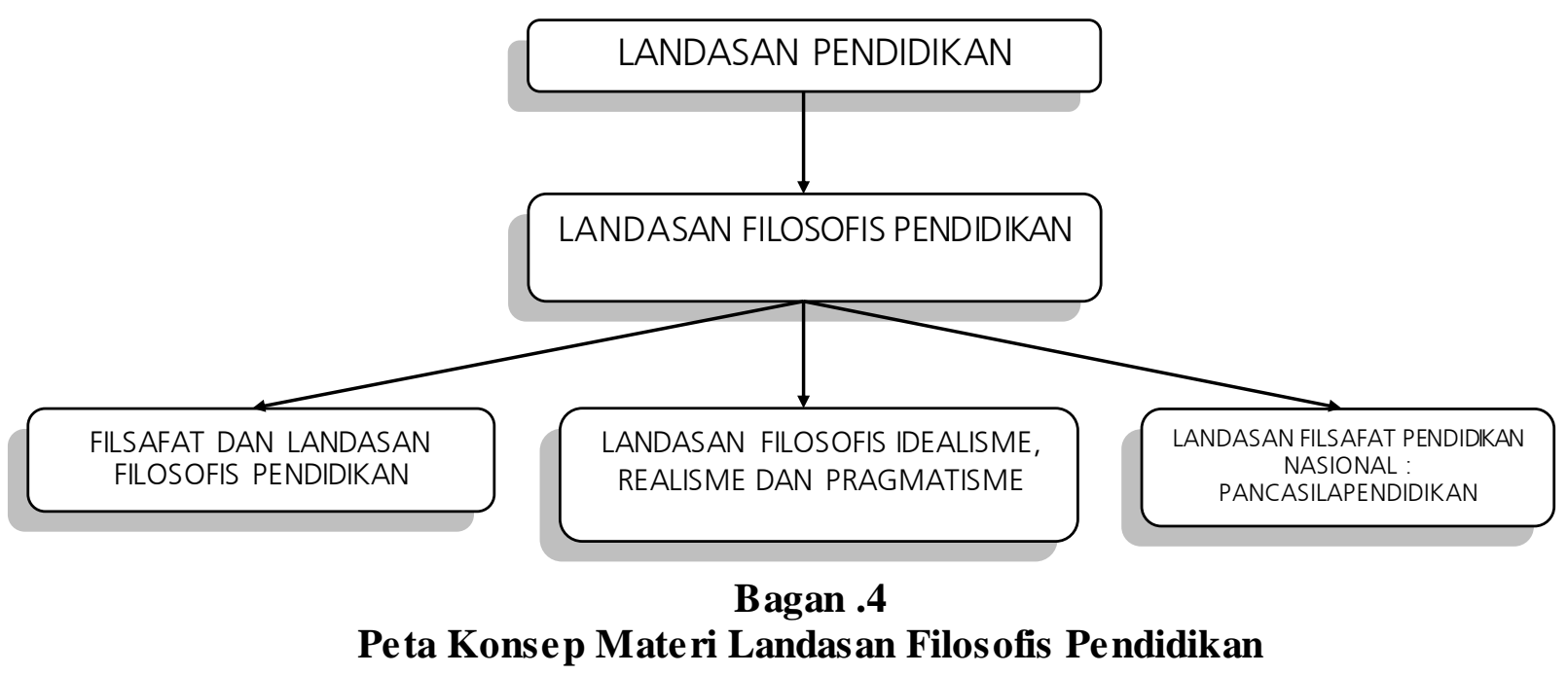

Semua pembahasan materi di buat kedalam model pemetaan konsep untuk selengkapnya bisa dilihat pada lembar lampiran.

\section{e. Hasil Uji Mata Kuliah Landasan Pendidikan dengan Menerapkan Model Pemetaan Konsep \\ Untuk mengetahui} peningkatan pembelajaran bermakna melalui penerapan model pemetaan konsep pada mata kuliah Landasan Pendidikan digunakan uji t. Uji $t$ merupakan salah satu teknik untuk menguji perbedaan sebelum dan sesudah perlakuan (penerapan model pemetaan konsep) dengan menggunakan disains percobaan sederhana yaitu $\mathrm{O} 1, \mathrm{X}, \mathrm{O} 2$, melalui rata-rata yang diperoleh pada masing-masing pengukuran. Berdasarkan hasil rekapitulasi dan perhitungan uji $\mathrm{t}$ diketahui gambaran skor rata-rata pada masing-masing pengukuran pre-test dan post-test sebagai berikut. 
Tabel .1

Deskrifsi Skor Rata-rata Pre-test dan Post-test

\begin{tabular}{|l|r|r|r|}
\hline & \multicolumn{1}{|c|}{ Mean } & \multicolumn{1}{c|}{$\begin{array}{c}\text { Std. } \\
\text { Deviation }\end{array}$} & \multicolumn{1}{|c|}{ N } \\
\hline PRE-TEST & 42,46 & 6,438 & 56 \\
POST- & 63,39 & 8,519 & 56 \\
TEST & & 56 & \\
\hline
\end{tabular}

Berdasarkan tabel 4.1 diketahui skor rata-rata pre-test sebesar 42,46 dan post-test sebesar 63,39 dengan jumlah sampel (N) 56 orang. Sedangkan standar deviasi pada skor rata-rata pre-test adalah 6 , 438 dan sandar deviasi pada skor rata-rata post-test sebesar 8,519. Melihat perubahan yang signifikan dari hasil test tersebut maka dapat disimpulkan bahwa hasil rata-rata post-test lebih besar dari rata-rata pre-test

Tabel .2

Daftar Nilai Correlations

\begin{tabular}{|l|l|r|r|}
\hline & \multicolumn{1}{|c|}{$\begin{array}{c}\text { PRE- } \\
\text { TEST }\end{array}$} & \multicolumn{1}{c|}{$\begin{array}{c}\text { POST- } \\
\text { TEST }\end{array}$} \\
\hline PRE-TEST & $\begin{array}{l}\text { Pearson } \\
\text { Correlation }\end{array}$ & 1 &, 061 \\
\cline { 2 - 4 } & Sig. (2-tailed) &. &, 656 \\
\cline { 2 - 4 } & $\mathrm{N}$ & 56 & 56 \\
\hline POST-TEST & $\begin{array}{l}\text { Pearson } \\
\text { Correlation }\end{array}$ &, 061 & 1 \\
\cline { 2 - 5 } & Sig. (2-tailed) &, 656 &. \\
\cline { 2 - 5 } & $\mathrm{N}$ & 56 & 56 \\
\hline
\end{tabular}

\section{E. SIMPULAN DAN SARAN}

Hasil

perhitungan

menunjukkan bahwa nilai korelasi yang muncul dan hasil perhitungan menyatakan signifikan yaitu $\mathrm{p}<0,01$ $(0,656)$ dengan hasil korelasi 0,061 hal ini menegaskan hasil yang signifikan dilihat dari hasil rata-rata pre-test dan post-test.

Dengan hasil seperti itu maka penerapan model pemetaan konsep pada mata kuliah Landasan Pendidikan dapat meningkatkan pembelajaran bermakna pada 
sampel penelitian (mahasiswa PGSD). Pada bagian pembahasan ini memfokuskan pada kajian penerapan model pemetaan konsep sesuai dengan kajian selama proses dan hasil penelitian. Berdasarkan data hasil penelitian di atas, maka dapat diuraikan beberapa hal sebagai berikut:

\begin{tabular}{lrr}
\multicolumn{2}{c}{ Penelitian ini menemukan } \\
bentuk instrument & standar \\
pengukuran & keberhasilan & belajar
\end{tabular} mata kuliah landasan pendidikan baik yang bersifat kualitatif maupun kuantitatif. Instrumen yang digunakan berupa soal ujian, pada proses penelitian ini tidak melewati prosedur pengembangan alat ukur baku, baik uji validitas maupun reliabilitas secara empirik melainkan melalui kajian tim peneliti dalam menyusun silabus, kompetensi dasar, indikator sampai penyusunan soalsoal yang di ujikan pada ujian tengah semester pada mata kuliah Landasan Pendidikan. Secara keseluruhan instrumen dalam penelitian ini digunakan sebagai alat uji keberhasilan dari penerapan model pemetaan konsep baik pada kegiatan pre-test maupun pada kegiatan posttest.

Silabus mata kuliah landasan pendidikan baku berorientasi pada model pemetaan konsep yang dilakukan melalui kegiatan pembelajaran fokus pada presentasi dan diskusi dengan menerapkan model pembelajaran pemetaan konsep. Evaluasi penilaian menggunakan pedoman observasi dan dilakukan Quiz yang disesuaikan dengan materi yang telah dipelajari sedangkan secara sumatif digunakan sebagai soal ujian tengah semester (UTS). Bentuk satuan acara perkuliahan (SAP) mata kuliah Landasan Pendidikan yang berorientasi pada model pemetaan konsep.

Penerapan model dilakukan melalui kegiatan presentasi dan diskusi yang menggunakan model pemetaan konsep yang mengandung materi dari mata kuliah Landasan Pendidikan. Hasil uji penerapan model pemetaan konsep menunjukkan adanya perubahan pembelajaran menjadi lebih bermakna pada mata kuliah Landasan Pendidikan, hal ini bisa dilihat dari perubahan hasil pre-test dan post test.

\section{F. REFERENSI}

Basri, S.2000. Teaching speaking. Makalah disampaikan pada Penataran Instruktur Guru Bahasa Inggris SLTP Swasta tanggal 8-19 Februari 2000 di Jakarta

Bobby De Porter dan Mike Hemacki, dkk.2000. Quantum learning. Bandung: Kaifa

Departemen Pendidikan dan Kebudayaan. 1993. GBPP Bahasa Inggris SLTP 1994. Jakarta: Bidang Dikmenum Kanwil Dikbud Provinsi Jawa Timur

Departemen Pendidikan Nasional. 2002. Contextual teaching and learning. Jakarta: Direktorat Jendran Pendidikan Dasar dan Menengah Direktorat Pendidikan Lanjutan Pertama. 
Hadfield, J. 1986. Harap's Communication Games. Australia: Thomas Nelson and Son Ltd.

Hasman, M.A. 2000. The Importance of English . Wasingthon: English Teaching Forum.

Mulyasa, E. 2002. Kurikulum Berbasis Kompetensi: Konsep, Karakteristik dan Implementasi. Bandung: Remaja Rosdakarya.

Sardiman A.M. 2001. Interaksi dan Motivasi Belajar Mengajar. Jakarta: Rajawali Press.

Sub Koordinator MKDP Landasan Pendidikan, 2009. Landasan Pendidikan. Bandung: Universitas Pendidikan Indonesia 